\title{
Assessment of Tolerance of Zea mays L. and Physico- chemical Properties of Soil at Flood Affected Site in Bayelsa State, Nigeria
}

\author{
Osim, Samuel E.., Etukudo, Mbosowo M.**, Eze, Ukamaka P. ${ }^{* * *}$, Okoye, Simonpeter U. ${ }^{* * * *}$, Ekwueme, David C ${ }^{* * * * *}$. \\ *Department of Plant Science and Biotechnology, Cross River State University of Science and Technology. Nigeria \\ ${ }^{* *}$ Department of Biology, Federal University Otuoke, Bayelsa State, Nigeria \\ *** Department of Science Laboratory Technology, Federal Polytechnic, Ekowe, Bayelsa State, Nigeria \\ **** Department of Microbiology, Federal University Otuoke, Bayelsa State, Nigeria
}

DOI: $10.29322 / I J S R P .10 .10 .2020 . p 10654$

http://dx.doi.org/10.29322/IJSRP.10.10.2020.p10654

\begin{abstract}
Assessment of tolerance of Zea mays and physiochemical properties of soil at flooded areas was conducted in Yenagoa, Bayelsa State, Nigeria. Five (5) sampling units (P1, $P 2, P 3, P 4$ and P5) in an area prone to seasonal flooding were selected alongside a non-flooded terrain (control-P0). Germination studies were conducted two (2) weeks before the onset of flood in the experimental sites, while a corresponding set up was maintained at the control site. Three (3) seeds of the crop were sown in the experimental soil per planting point with five (5) replicates. The experimental set up was maintained under natural light condition for twenty eight (28) days. Physicochemical properties of the experimental soil and the test crop growth parameters were examined. Soil $\mathrm{pH}$, the contents of nitrogen and phosphorus were lower in the flooded soils relative to that of the non-flooded area. Higher contents of exchangeable calcium, and potassium were recorded at the normal soil relative to the flooded soil. The proportions of clay and silt fractions in the flooded soils were higher relative to that of the non-flooded area. The shoot length, root length, fresh weight and dry weight of the test crop were lower in the flooded soils comparable to the normal soil. This study suggests that the impacts of flooding on agricultural soils are deleterious, thus, appropriate management strategies are required to reduce the effects of this menace on plants.
\end{abstract}

Index Terms-Zea mays, Soil Properties, Flood, Bayelsa State

\section{INTRODUCTION}

Flooding is one of the devastating environmental hazards, which results either from rainwater or by river water ${ }^{\mathbf{1 ; 2}}$, and is commonly found in some state of Nigeria such as Bayelsa, Cross Rivers, Akwa Ibom, Rivers, Delta, and others. This seasonal flooding of soils is considered a natural phenomenon, which occurs between May-October during the rainy season, and usually affects farmlands, forested areas as well as residential places ${ }^{3}$. The impacts of flood on soil physico-chemical properties are dependent on factors such as water balance, topography and subsurface ${ }^{4}$. Submergence of soil by flood usually causes both reversible and irreversible changes in physico-chemical properties of such soil ${ }^{5}$. The soil is a medium of plant growth, thus alteration of its physico-chemical properties have a serious impact on root development, and consequently on plant vegetative development ${ }^{6}$. Therefore, plant grown on flooded areas are affected by stress conditions, because the diffusion of gases through soil pores is inhibited by the excess water contents, which the growing roots do not require ${ }^{7}$. The inundation of an area with water can cause hazardous chemicals to be released into the soil ${ }^{\mathbf{8} ; \mathbf{9}}$. In rural areas, runoff from flooded areas can carry with it eroded soil containing fertilizers, herbicides and insecticides. Runoff from motorways, roads and bridges may contain heavy metals, petroleum hydrocarbons and polycyclic aromatic hydrocarbons. Runoff from inundated waste sites may contain a variety of toxic chemicals, depending on its initial source ${ }^{\mathbf{1 0}}$.

This study becomes increasingly important because plant species potentials are faced with sources of strong disturbances such as destructive practices, pollution, invasive species, mass mortality outbreaks, bush fires, flooding, and poor development plans and programs leading to profound structural and functional changes 11;12. The study area, Yenagoa, Bayelsa State, has a riverine and estuarine settings with many of its communities completely surrounded by water, and lies in the tropical zone in the Niger Delta region of Nigeria ${ }^{\mathbf{1 3}}$. The test crop Zea mays (Poaceae) is cultivated as one of the stable food and economic crops in farmlands in Bayelsa State, Nigeria. It is used as a stable food crop and constitutes a major component to many important dishes, as well as a basal medium and raw material for industries 14. The characteristic water terrain of Bayelsa State with its attendant's problem of flooding justifies the increasing need for this study. This present study was carried out to evaluate the tolerance of Zea mays at its seedling stage to flooded soil conditions as well as the physical and chemical characteristics of the experimental soil.

\section{MATERIALSS AND METHODS}

Study Area: The study was conducted in an area prone to seasonal flooding, alongside a non-flooded terrain, which served as control treatment, in Yenagoa, Bayelsa State, Nigeria. Bayelsa State has a riverine and estuarine setting with many of 
its communities completely surrounded by water, and lies in the heaviest rainfall area of Nigeria, with heavy rain forest and short dry season. The research area is characterized by a mean maximum monthly temperature ranging from $26^{\circ} \mathrm{C}$ to $31^{\circ} \mathrm{C}$. The State is geographically located within latitude $4 \hat{\mathrm{A}}^{\circ} 15^{\prime}$ North and latitude $5 \hat{\mathrm{A}}^{\circ} 23^{\prime}$ South. It is also within longitudes $5 \hat{\mathrm{A}}^{\circ} 22^{\prime}$ West and $6 \hat{A}^{\circ} 45^{\prime}$ East ${ }^{13 ; 15}$.

Analysis of Soil Samples: Soil samples (0-15cm depth) collected from the study sites, Yenagoa, Bayelsa State, Nigeria were analysed using standard methods for determining soil physico-chemical properties ${ }^{\mathbf{1 6}}$.

\section{Germination Studies}

Five (5) sampling units (P1, P2, P3, P4 and P5) in an area prone to seasonal flooding were selected alongside a non-flooded terrain (control-P0). Germination studies were conducted two (2) weeks before the onset of flood in the experimental sites, while a corresponding set up was maintained at the control site. Seeds of Zea mays obtained from local farmers in Yenagoa, Bayelsa State, Nigeria, were surface sterilized with 5\% ethanol for 30 seconds and thoroughly washed several times with sterile distilled water. The seeds were air dried for few minutes. Three (3) seeds of the crop were sown in the experimental soil per planting point with five (5) replicates. The experimental set up was maintained at a mean minimum temperature of $22.42^{\circ} \mathrm{C}$ and a mean maximum temperature of $31.06^{\circ} \mathrm{C}$, under natural light condition for twenty eight (28) days.

Determination of shoot length and root length: The shoot length and root length of the test crop were measured with a meter rule and expressed in centimetres.

Determination of moisture content: The plant materials were harvested and repeatedly washed with sterile-distilled water using a sieve to avoid loss of plant parts. Blotting papers were used to dry the seedlings and the fresh weight measured using mettler-p-165 weighing balance. The fresh plant materials were dried in a Gallen Kamp oven maintained at $65^{\circ} \mathrm{c}$ for 2 days to a constant weight in order to determine the dry weight.

Statistical analysis: Data analysis was carried out using analysis of variance (ANOVA) ( $\mathrm{P}<0.05)$ using appropriate statistical method ${ }^{17}$.

\section{RESULTS AND DISCUSSION}

The mean $\mathrm{pH}$ values ranged from 5.20 to 5.70 at the flooded soils relative to a value of 6.40 at the non-flooded soil (control) (Table $1)$. The low $\mathrm{pH}$ value of the flooded soils relative to the control soil is an indication of modification of the soil conditions at the flooded soil. This clearly shows a moderate acidic soil condition at the experimental soil, however, these values are within the range suitable for optimum growth performance of crops. In flooded soil, reduction in $\mathrm{pH}$ has been reported to be caused by the accumulation of carbonic acid formed from trapped carbon dioxide produced from respiration ${ }^{18}$. The presence of heavy metals in flooded soils may pose a health risk on local communities growing and consuming food crops and vegetables in contaminated sites. The sequence of contamination involves contamination of soils by chemicals, the potential uptake by crops and the possible chronic and long term toxic effects in humans ${ }^{19 ; 20}$. Although plant uptake of heavy metals depends significantly on the metals as well as the prevailing soil conditions, several studies have indicated that crops grown on heavy metal contaminated soils have higher concentrations of heavy metals than those grown in uncontaminated soil 21;22;23.

The total organic carbon ranged from 0.34 to $0.62 \%$ at the flooded soil (P1-P5) comparable to the contents of $0.52 \%$ at the control soil (P0)-(Table 1). The contents of total nitrogen at the five sampling units of the flooded soil were 0.034, 0.050, 0.023, 0.042 , and $0.020 \%$ at $\mathrm{P} 1, \mathrm{P} 2, \mathrm{P} 3, \mathrm{P} 4$, and $\mathrm{P} 5$, respectively, relative to the value of $0.063 \%$ at the control soil (P0). The phosphorus contents at the five sampling units of the flooded soil were $20.40,12.26,8.32,21.30$, and $20.16 \mathrm{mg} / \mathrm{kg}$ at P1, P2, P3, $\mathrm{P} 4$, and P5, respectively, comparable to the content of $28.07 \mathrm{mg} / \mathrm{kg}$ at the control soil (P0) (Table 1). The contents of exchangeable bases varied considerably $(\mathrm{P}<0.05)$ among the five sampling units at the flooded soils, while higher contents of exchangeable calcium, and potassium were recorded at the control soil relative to the flooded soil (Table 1). The proportion of clay and silt fractions in the flooded soils increased in relation to that of the non-flooded area (Table 1). Changes in soil chemistry are usually viewed as major characteristics in soil saturated with water as indicated in this study. Water is known to decrease the mobility and availability of metal ions, and mineral nutrients due to its properties of acting as a solvent for ions and soluble compounds. This prevailing soil condition in the flooded soils has caused microbial respiration to enhance water soluble compounds such as nitrate, perchorate, manganese, ferric iron, sulphate and carbon dioxide to act as electron acceptor ${ }^{24}$. The reduced nature of aggregate stability in flooded soil has caused organic carbon to be more soluble like metals and minerals under reducing conditions ${ }^{\mathbf{2 5}}$. Nitrogen may be limited in anaerobic soil condition. The occurrence of nitrogen in soils and sediments is usually in form of complex organic substances, ammonia, molecular nitrogen, nitrite and nitrate. Organic nitrogen mineralization in flooded soil is inhibited at the ammonia stage due to oxygen deficiency, thus leading to accumulation of ammonia in anaerobic soil ${ }^{26 ; 27 ; 28}$.

The shoot length recorded higher values $(\mathrm{P}<0.05)$ at the control soil (P0) than those of the flooded soils (P1-P5). The root length ranged from $4.20-5.10 \mathrm{~cm}$ at the flooded soil (P1-P5) relative to that of the control $-\mathrm{P} 0(8.20 \mathrm{~cm})$. Lower values of fresh weight and dry weight were recorded $(\mathrm{P}<0.05)$ at all the five $(5)$ sampling units (P1-P5) relative to that of the control (P0) (Table 2). The reduced growth parameters of Zea mays at the flooded soil may be attributed to anaerobic soil conditions created in the saturated soil. The flooded soil is characterized by a decline in oxygen level, thus triggering a sequence of changes in the physical and chemical properties of the affected soil ${ }^{7}$. These changes often result in aggravated proportion of reduced metal ions, organic acids and volatile acids, which are inhibitory to root growth ${ }^{7 ; 29}$. These changes affect the plant metabolic activities such that stomatal resistance increases, photosynthesis and root hydraulic conductivity decline and translocation of photoassimilates is reduced. The blockage of a greater percentage of soil pores space by the presence of water inhibits root growth due to low oxygen availability ${ }^{30 ; 31}$. 
In addition, the modification of soil properties greatly affects gas diffusion coefficient in the soil, which depends on texture, structure, distribution, size and pores connectivity ${ }^{32}$. The saturation of soil pores with water also causea chemical modification in soil parameters such as $\mathrm{pH}$ value and accumulation of toxic products ${ }^{2}$. A reduced pore space in a flooded soil with less than $20 \%$ has been reported to affect soil properties such as texture, structure, water content, mineralogy of clays and sodium absorption, thus leading to inhibition in microbial activity and plant growth ${ }^{28 ; 33 ; 34}$. In general, the reduced condition of soil with its associated reduction in the capacity to extract nutrients will decrease the nitrogen and phosphorus contents of plant. Although, other mineral elements such as iron and manganese contents will increase because of their reduction in soluble forms, these changes in contents of various elements may affect plant growth due to their effects on root metabolism ${ }^{35}$.

Table 1: Physical and chemical properties of experimental soil

\begin{tabular}{|c|c|c|c|c|c|c|}
\hline $\begin{array}{l}\text { Sampling } \\
\text { sites }\end{array}$ & \multirow[t]{2}{*}{$\begin{array}{l}\text { Po } \\
\text {-Control }\end{array}$} & \multirow[t]{2}{*}{ P1 } & \multirow[t]{2}{*}{$\mathrm{P} 2$} & \multirow[t]{2}{*}{ P3 } & \multirow[t]{2}{*}{ P4 } & \multirow[t]{2}{*}{ P5 } \\
\hline Parameters & & & & & & \\
\hline $\mathrm{pH}$ & $\begin{array}{l}6.40 \pm \\
0.32\end{array}$ & $\begin{array}{l}5.30 \pm \\
0.24\end{array}$ & $\begin{array}{l}5.60 \pm \\
0.33\end{array}$ & $\begin{array}{l}5.40 \pm \\
0.20\end{array}$ & $\begin{array}{l}5.70 \pm \\
0.81\end{array}$ & $\begin{array}{l}5.20 \pm \\
0.17\end{array}$ \\
\hline TOC $(\%)$ & $\begin{array}{l}0.52 \pm \\
0.07\end{array}$ & $\begin{array}{l}0.62 \pm \\
0.03\end{array}$ & $\begin{array}{l}0.34 \pm \\
0.02\end{array}$ & $\begin{array}{l}0.17 \pm \\
0.05\end{array}$ & $\begin{array}{l}0.46 \pm \\
0.02\end{array}$ & $\begin{array}{l}0.38 \pm \\
0.03\end{array}$ \\
\hline $\begin{array}{ll}\text { Total } & \mathrm{N} \\
(\%) & \end{array}$ & $\begin{array}{l}0.063 \pm \\
0.01\end{array}$ & $\begin{array}{l}0.034 \\
\pm 0.01\end{array}$ & $\begin{array}{l}0.050 \\
\pm 0.02\end{array}$ & $\begin{array}{l}0.023 \\
\pm 0.01\end{array}$ & $\begin{array}{l}0.042 \\
\pm 0.02\end{array}$ & $\begin{array}{l}0.020 \pm \\
0.01\end{array}$ \\
\hline $\mathrm{P}(\mathrm{mg} / \mathrm{kg})$ & $\begin{array}{l}28.07 \pm \\
0.47\end{array}$ & $\begin{array}{l}20.40 \\
\pm 0.13\end{array}$ & $\begin{array}{l}12.26 \\
\pm 0.20\end{array}$ & $\begin{array}{l}8.32 \pm \\
0.14\end{array}$ & $\begin{array}{l}21.30 \\
\pm 0.52\end{array}$ & $\begin{array}{l}20.16 \pm \\
0.77\end{array}$ \\
\hline $\begin{array}{l}\mathrm{Ca}^{2+} \\
(\mathrm{mg} / \mathrm{kg})\end{array}$ & $\begin{array}{l}4.20 \pm \\
0.49 \\
\end{array}$ & $\begin{array}{l}2.20 \pm \\
0.22 \\
\end{array}$ & $\begin{array}{l}2.42 \pm \\
0.34 \\
\end{array}$ & $\begin{array}{l}1.87 \pm \\
0.13 \\
\end{array}$ & $\begin{array}{l}2.04 \pm \\
0.10 \\
\end{array}$ & $\begin{array}{l}1.80 \pm \\
0.15 \\
\end{array}$ \\
\hline $\begin{array}{l}\mathrm{Mg}^{2+} \\
(\mathrm{mg} / \mathrm{kg})\end{array}$ & $\begin{array}{l}0.62 \pm \\
0.08\end{array}$ & $\begin{array}{l}2.27 \pm \\
0.32\end{array}$ & $\begin{array}{l}3.16 \pm \\
0.23\end{array}$ & $\begin{array}{l}1.30 \pm \\
0.18\end{array}$ & $\begin{array}{l}1.21 \pm \\
0.25\end{array}$ & $\begin{array}{l}2.06 \pm \\
0.33\end{array}$ \\
\hline $\begin{array}{l}\mathrm{Na}^{+} \\
(\mathrm{mg} / \mathrm{kg})\end{array}$ & $\begin{array}{l}0.28 \pm \\
0.04\end{array}$ & $\begin{array}{l}0.17 \pm \\
0.03\end{array}$ & $\begin{array}{l}0.24 \pm \\
0.06\end{array}$ & $\begin{array}{l}0.32 \pm \\
0.05\end{array}$ & $\begin{array}{l}0.20 \pm \\
0.02\end{array}$ & $\begin{array}{l}0.36 \pm \\
0.06\end{array}$ \\
\hline $\begin{array}{l}\mathrm{K}^{+} \\
(\mathrm{mg} / \mathrm{kg})\end{array}$ & $\begin{array}{l}0.19 \pm \\
0.02\end{array}$ & $\begin{array}{l}0.10 \pm \\
0.03\end{array}$ & $\begin{array}{l}0.05 \pm \\
0.03\end{array}$ & $\begin{array}{l}0.14 \pm \\
0.07\end{array}$ & $\begin{array}{l}0.17 \pm \\
0.02\end{array}$ & $\begin{array}{l}0.15 \pm \\
0.04\end{array}$ \\
\hline $\begin{array}{l}\mathrm{H}^{+} \\
(\mathrm{mg} / \mathrm{kg})\end{array}$ & $\begin{array}{l}0.30 \pm \\
0.03 \\
\end{array}$ & $\begin{array}{l}0.60 \pm \\
0.04 \\
\end{array}$ & $\begin{array}{l}0.40 \pm \\
0.02 \\
\end{array}$ & $\begin{array}{l}0.20 \pm \\
0.02 \\
\end{array}$ & $\begin{array}{l}0.30 \pm \\
0.05 \\
\end{array}$ & $\begin{array}{l}0.50 \pm \\
0.02 \\
\end{array}$ \\
\hline $\begin{array}{l}\mathrm{Al}^{3+} \\
(\mathrm{mg} / \mathrm{kg})\end{array}$ & $\begin{array}{l}0.10 \pm \\
0.02\end{array}$ & $\begin{array}{l}1.24 \pm \\
0.13\end{array}$ & $\begin{array}{l}1.07 \pm \\
0.18\end{array}$ & $\begin{array}{l}0.70 \pm \\
0.06\end{array}$ & $\begin{array}{l}0.20 \pm \\
0.04\end{array}$ & $\begin{array}{l}1.40 \pm \\
0.25\end{array}$ \\
\hline $\begin{array}{l}\text { ECEC } \\
(\mathrm{mg} / \mathrm{kg})\end{array}$ & $\begin{array}{l}6.72 \pm \\
0.40\end{array}$ & $\begin{array}{l}5.26 \pm \\
0.54\end{array}$ & $\begin{array}{l}4.87 \pm \\
0.32\end{array}$ & $\begin{array}{l}4.70 \pm \\
0.60\end{array}$ & $\begin{array}{l}4.62 \pm \\
0.28\end{array}$ & $\begin{array}{l}4.66 \pm \\
0.90\end{array}$ \\
\hline Sand (\%) & $\begin{array}{l}90.40 \pm \\
0.58\end{array}$ & $\begin{array}{l}78.55 \\
\pm 0.31\end{array}$ & $\begin{array}{l}82.24 \\
\pm 0.45\end{array}$ & $\begin{array}{l}76.74 \\
\pm 0.72\end{array}$ & $\begin{array}{l}70.49 \\
\pm 0.27\end{array}$ & $\begin{array}{l}73.30 \pm \\
0.69\end{array}$ \\
\hline Silt (\%) & $\begin{array}{l}4.87 \pm \\
0.44\end{array}$ & $\begin{array}{l}4.34 \pm \\
0.27\end{array}$ & $\begin{array}{l}5.21 \pm \\
0.43\end{array}$ & $\begin{array}{l}5.77 \pm \\
0.68\end{array}$ & $\begin{array}{l}6.60 \pm \\
0.37\end{array}$ & $\begin{array}{l}5.52 \pm \\
0.92\end{array}$ \\
\hline Clay (\%) & $\begin{array}{l}4.73 \pm \\
0.63\end{array}$ & $\begin{array}{l}17.11 \\
\pm 0.49\end{array}$ & $\begin{array}{l}12.55 \\
\pm 0.46\end{array}$ & $\begin{array}{l}17.49 \\
\pm 0.94\end{array}$ & $\begin{array}{l}22.91 \\
\pm 0.53\end{array}$ & $\begin{array}{l}21.18 \pm \\
0.42\end{array}$ \\
\hline
\end{tabular}

Mean \pm standard error of 5 replicates

Table 1: Physical and chemical properties of experimental soil

\begin{tabular}{|l|l|l|l|l|l|l|}
\hline $\begin{array}{l}\text { Sampling } \\
\text { sites }\end{array}$ & $\begin{array}{l}\text { Po } \\
\text {-Control }\end{array}$ & P1 & P2 & P3 & P4 & P5 \\
\cline { 1 - 6 } Parameters & & & & & \\
\hline Shoot length & $6.40 \pm$ & $5.30 \pm$ & $5.60 \pm$ & $5.40 \pm$ & $5.70 \pm$ & $5.20 \pm$ \\
(cm) & 0.16 & 0.43 & 0.65 & 0.47 & 0.29 & 0.61 \\
\hline Root length & $0.52 \pm$ & $0.62 \pm$ & $0.34 \pm$ & $0.17 \pm$ & $0.46 \pm$ & $0.38 \pm$ \\
(cm) & 0.02 & 0.09 & 0.06 & 0.05 & 0.02 & 0.05 \\
\hline Fresh & $0.063 \pm$ & 0.034 & 0.050 & 0.023 & 0.042 & $0.020 \pm$ \\
weight (g) & 0.01 & \pm 0.02 & \pm 0.06 & \pm 0.03 & \pm 0.02 & 0.03 \\
\hline
\end{tabular}

\begin{tabular}{|c|c|c|c|c|c|c|}
\hline $\begin{array}{l}\text { Dry } \\
\text { (g) }\end{array}$ & $\begin{array}{l}28.07 \pm \\
0.60\end{array}$ & & & $\begin{array}{l}8.32 \pm \\
0.17\end{array}$ & & \\
\hline
\end{tabular}

Mean \pm standard error of 5 replicates

\section{CONCLUSION}

The study reported a marked variation in the soil physical and chemical properties between the flooded soils and the nonflooded area. Soil $\mathrm{pH}$, the contents of nitrogen and phosphorus were lower in the flooded soils relative to that of the non-flooded area. The contents of exchangeable bases varied considerably among the five sampling units at the flooded soils, while higher contents of exchangeable calcium, and potassium were recorded at the control soil relative to the flooded soil. The proportions of clay and silt fractions in the flooded soils were higher relative to that of the non-flooded area. The crop growth parameters assessed were lower in the flooded soils comparable to the normal soil. This study revealed that appropriate management strategies are required to reduce the deleterious impacts of flooding on plants and agricultural soils.

\section{ACKNOWLEDGMENT}

We remain grateful to Mr. Simonpeter Uche Okoye for painstakingly collecting the research samples, sorting and assembling them for analysis.

\section{REFERENCES}

[1] K. F. Akter, Z. H. Khan, M. S. Hussain, A. R. Mazumder Physico-Chemical characteristics of the seasonally flooded soils of Bangladesh and their management implications. Dhaka Univ. J. Biol. Sci. 20(2), 2011, 173-182.

[2] M. Irfan, S. Hayat, Q. Hayat, S. Afroz, A. Ahmad. 2010. Physiological and biochemical changes in plants under waterlogging. Protoplasma 241, 2010, 3-17.

[3] S. A. Osakwe. Evaluation of physicochemical characteristics of soils in the flood disaster affected areas of Isoko region of Delta State, Nigeria. IOSR Journal of Applied Chemistry (IOSR-JAC), 7(5; I), 2014), 24-31

[1] A. B. P. Carvalho, C. P. Ozório, Avaliação sobre os banhados do Rio Grande do Sul, Brasil. Revista de Ciências Ambientais, 2, 2007, 83-95.

[2] F.N. Ponnamperuma. Chemical kinetics of wetland rice soil relative to soil fertility. In: Wetland Soils-Characterizatoin, Classification and Utilization. International Rice Research Institute (IRRI), Los Banos, Philippines, 1985.

[3] A. Pierret, C. Doussan, Y. Capowiez, F. Bastardie, L. Pages. Root functional architecture: A framework for modeling the interplay between roots and soil. Vadose Zone Journal 6, 2007, 269-281

[4] M. Morales-Olmedo, M. Ortiz, G. Selles. Effects of transient soil waterlogging and its importance for rootstock selection. Chilean J. Agric. Res. 75,1, 2015.

[8] B. Menne, V. Murray. Floods in the WHO European Region, health effects and their prevention. Copenhagen: WHO Regional Office for Europe; 2013 (http://www.euro.who.int/_data/assets/pdf_file/0020/189020/e96853.pdf, accessed 7 July 2017).

[9] E. Euripidou, V. Murray. Public health impacts of floods and chemical contamination. Journal of Public Health. 26(4), 2004, :376-83.

[10] S. Young, L. Balluz, J. Malilay. Natural and technologic hazardous material releases during and after natural disasters: a review. Science of the Total Environment. 322(1-3), 2004, 3-20.

[11] G. Cox. Laboratory manual of general ecology, $6^{\text {th }}$ Ed. D. Ubugue, Iowa: William C. Brown Publishing. 1990.

[12] J.J.D.Greenword. Basic techniques in population studies. In: William J. Sutherland (eds), Ecological Census Techniques. United Kingdom, Cambridge University Press. 2000, Pp. 12-105.

[13] Niger Delta Source: Bayelsa State. http://nigeriadeltasource.com/bayelsa, 2014. 
[14] D. J. Udo, B.A. Ndon, P.E. Asuquo, N.U. Ndaeyo. Crop production techniques for tropics Nigeria: Concept Publication Ltd, 2005

[15] Bayelsa New Media Team News: Bayelsa State General Information Area. www.bayelsa.gov.ng/www.bayelsanewmediateam.com, 2012.

[16] A.O.A.C. Association of Official Analytical chemists. Method of Analysis, Washington D.C, 2003

[17] A. E. Ogbeibu. Biostatistics: A practical approach to research and data handling. Mindex Publishing Company Limited, Benin, 2005.

[18] G.J. Kirk. The biogeochemistry of submerged soils. Chichester: Wiley, 2004.

[19] M. M. Etukudo, I. A. Nwaukwu, S. Habila. The effect of sawdust and goatdung supplements on growth and yield of Okro (Abelmoschus esculentus L. Moench) in diesel oil contaminated soil. Journal of Research in Forestry, wildlife and Environment. 3(2), 2011, 92- 98.

[20] G. Nabulo, O. H. Origa, G.W. Nasinyama, D. Cole. Assessment of Zn, Cu, $\mathrm{Pb}$ and $\mathrm{Ni}$ contamination in wetland soils and plants in the Lake Victoria basin. International Journal of Environmental Science and Technology, 5 (1), 2008, 65-74

[21] G.C. Elekes, G. Busuloc. The modeling of phytoremediation process for soils polluted with heavy metals. Agronomy Series of Scientific Research/ Lurari Scientific Series, 54 (2), 201113

[22] G. Nabulo. Assessment of heavy metal contamination of food crops and vegetables grown in and around Kampala city, Uganda, Ph.D. Thesis, Markerere University. 2006

[23] Q. Wang, Y. Cui, Y. Dong. Phytoremediation of polluted waters potential and prospects of wetland plants. Acta Biotechnology. 22(1-2), 2008,199208.

[24] H. Greenway, A. William, D.C. Timothy. Conditions leading to high CO2 $(>5 \mathrm{kPa})$ in waterlogged-flooded soils and possible effects on root growth and metabolism. Annals of Botany, 98, 2006, 9-32.

[25] A.B. De-Campos, A. I. Mamedov, C. Huang. Short-Term Reducing Conditions Decrease Soil Aggregation. Soil Science Society of America Journal, 73(2), 2009, 550

[26] D. C. Olk, M.I. Samson, P. Gapas. Inhibition of nitrogen mineralization in young humic fractions by anaerobic decomposition of rice crop residues. Eur. J. Soil. Sci. 58, 2007, 270-281.

[27] D.C. Olk, K.G. Cassman, E.W. Randall, P. Kinchesh, L.J. Sanger, J.M Anderson. Changes in chemical properties of organic matter with intensified rice cropping in tropical lowland soil. Eur. J. Soil Sci. 47, 1996, 293-303.

[28] N. C. Brady, R.R. Weil. The nature and properties of soils. $14^{\text {th }}$ ed.. Prentice Hall, Upper Saddle River, New Jersey, USA., 2008, p. 965.

[29] P. Perata, W. Armstrong, C.J. Voesenek. Plants and flooding stress. New Phytologist, 190, 2011, 269-273
[30] A. R. Dexter. Advances in characterization of soil structure. Soil and Tillage Research, 11, 1988, 199-238.

[31] F.J. Cook, J.H. Knight. Oxygen transport to plant roots. Soil Science Society of America Journal, 67, 2003, 20-31.

[32] P. Moldrup, T. Olesen, T. Komatsu, P. Schjonning, D.E. Rolston. Tortuosity, diffusivity, and permeability in the soil liquid and gaseous phases. Soil Science Society of America Journal, 65, 2001, 613-623.

[33] S. R. Pezeshki, J.H. Pardue, R.D. DeLaune. Leaf gas exchange and growth of flood-tolerant and flood-sensitive tree species under low soil redox conditions. Tree Physiology, 16, 1996, 453-458.

[34] E. Tete, V. Viaud, C. Walter. Organic carbon and nitrogen mineralization in a poorly-drained mineral soil under transient waterlogged conditions: an incubation experiment. European Journal of Soil Science, 66, 2015, 427437.

[35] M.C. Drew. Oxygen deficiency and root metabolism: Injury and acclimation under hypoxia and anoxia. Annual Review of Plant Physiology and Plant Molecular Biology, 48, 1997, 223-250.

\section{AUTHORS}

First Author -Dr. Samuel E. Osim, Senior Lecturer, Cross River State University of Science and Technology. Nigeria.

Second Author- Dr. Mbosowo M. Etukudo, Associate Professor of Plant Physiology, Federal University Otuoke, Bayelsa State, Nigeria.

Third Author - Ukamaka P. Eze, B.Sc., Federal Polytechnic, Ekowe, Bayelsa State, Nigeria.

Fourth Author-Simonpeter Uche Okoye, B.Sc., M.Sc., Federal University Otuoke, Bayelsa State, Nigeria.

Fifth Author- David C. Ekweme, B.Sc., Federal University Otuoke, Bayelsa State, Nigeria.

Correspondence Author - Dr. Mbosowo M. Etukudo, mbosombosowo@yahoo.com, mbosombosowo@gmail.com $+2347032448796$ 